[Vicino Oriente XXI (2017), pp. 197-210]

\title{
A NOTE ON AN UMAYYAD CARVED IVORY PLAQUE KEPT AT THE WALTERS ART GALLERY
}

\author{
Michelina Di Cesare - Sapienza University of Rome
}

\begin{abstract}
This paper proposes an iconographical and stylistic analysis of a carved ivory plaque kept at the Walters Art Gallery in Baltimore (acc. no. 71.62). It will show that it is not a Coptic artefact featuring a Sasanian king, as assumed until now, but an Umayyad artefact which must be contextualised within a specific tradition of imagery related to the expression of the Umayyad concept of Caliphal authority.
\end{abstract}

Keywords: Umayyad art; Sasanian art; post-Sasanian art; royal imagery; Caliphal authority

\section{A COPTIC ARTEFACT}

Sometime before 1931 Henry Walters acquired from Dikran Kelekian a carved ivory plaque said to have been found at Sohag, Egypt. Currently in storage at the Walters Art Gallery in Baltimore, this plaque is identified by accession number 71.62 (fig. 1). ${ }^{1}$

Though it is not entirely preserved, it can be inferred that its original dimensions were $9.8 \times 17.6 \mathrm{~cm} .^{2}$ The surface is carved in bas-relief. A frame delimits a canopy supported by two columns: only the base and part of the shaft of the left one are preserved, while on the right the whole shaft and the capital are still intact. The latter supports a reversed semi-arch - which possibly joined a similar symmetrical structure on the right, now lost - the span of which is filled by a vine-leaf bent into a semi-arch shape, thus mirroring the curve of the reversed semi-arch. This structure is inhabited by a male human figure viewed frontally and sitting on a backless and armless seat, the legs of which are vegetal in shape and curve inward where they join the stool seat. The figure sits with its arms bent outward at the elbows, its hands hold a sword - the right one just below the pommel of the hilt, the left where the cross-guard should be - positioned vertically between its legs. These are also bent outward at the knees, while the feet are turned outward at $180^{\circ}$, the heels joining at the point of the sword. The stool, feet and sword rest on the lower frame of the plaque. The figure's face is elongated, as is the nose, which is seen frontally and joins the eyes at the dorsal bridge. The eyes, surmounted by eyebrows, are drawn without lids with an external stroke which slightly elongates the protruding eyeballs; the pupils are pierced. The man wears a beard with a rounded bottom and an integrated moustache beneath which his full lips appear. Two curly locks of hair are preserved on the left side of the head. This is surmounted by a headgear - which is distinguished from the hair by different types of strokes - consisting of two symmetrical wing-like elements with a triangular element rising above their conjunction. Elements of the clothing are also identified by different renderings of the drapery. Parallel double short strokes curving upwards characterize the garment that covers the upper part of the body down to the waist and elbows; the sleeves, which cover the forearms down to the wrists, present shorter strokes along the inner and outer profile,

1 Ross 1940; Brooklyn 1941, no. 107; Baltimore 1947, no. 159; http://art.thewalters.org/detail/8959/seatedking/.

2 See footnote 1.

ISSN 0393-0300

e-ISSN 2532-5159 
almost converging in a herringbone. This arrangement suggests that the figure is wearing a tight short-sleeved caftan over a long-sleeved tunic. The drapery of the garment covering the lower part of the body from the waist to the knees consists of parallel curved strokes; perpendicular to the profile of the thighs, they are arranged symmetrically to the right and left of the sword and drop downward, thus rendering the lower part of a ruffled caftan. Below the knees, the drapery changes again: it consists of parallel strokes curving downward but perpendicular to the profile of the leg. They are arranged symmetrically to the right and left of the sword and are shorter closest to the ankles, thus suggesting a pair of loose trousers narrowing at the ankles. The footwear is difficult to determine but its lower profile is "plumed" and reminiscent of the triangular upper element of the headgear.

This plaque was firstly analysed by Ross in $1940 .{ }^{3}$ He recognized the human figure as a Sasanian king through comparison with the enthroned sovereign - whom he identified as Khusraw I (531-579) or Khusraw II (590-628) - carved on the crystal rock medallion set in the middle of the so-called "Khusraw Cup". ${ }^{4}$ According to Ross, the arrangement of the scene, the architectural elements and the style of drapery were features characterizing $7^{\text {th }}$ century Coptic artefacts. Though the forms were rigid and simplified, in his opinion, the accuracy in their rendering revealed that the artist actually intended to portray a Sasanian king, but not for decorative purposes as in a textile found in Antinoe and kept at the Musée Historique des Tissus in Lyon. ${ }^{5}$ Thus, Ross argued that the artist was satisfying a special commission, which would have suited the period of the Sasanian occupation of Egypt (619629). He also recalled that the provenance of the carved plaque, as stated by the dealer, seemed to be Sohag, which he deemed quite plausible. He maintained these conclusions in the brief entries published in the catalogues of the exhibitions on Pagan and Christian Egypt held at the Brooklyn Museum in $1941^{6}$ and on Early Christian and Byzantine Art held at the Baltimore Museum of Art in $1947 .^{7}$

In a review of the former, Der Narsessian referred to the figure represented on the plaque as a Sasanian king, and, though maintaining it was made within a Coptic context, questioned the dating proposed by Ross. He noticed that «the pose of the seated figure, the treatment of the drapery, the manner of carving, the facial type» were «all reminiscent of silver plates of the post-Sasanian period». ${ }^{8} \mathrm{He}$ also proposed comparing the artefact with an Egyptian ivory plaque also preserved at the Walters Art Gallery, representing the Virgin and Child, ${ }^{9}$ and Coptic manuscripts kept at the Pierpont Morgan Library, ${ }^{10}$ thus suggesting it should be dated to the $9^{\text {th }}$ century at the earliest.

Ross 1940

4 Paris, Bibliothèque nationale de France, acc. no. 379; see Harper - Meyer 1981, 111 ff., n. 56 and pl. 33. See also below.

5 Lyon, Musée des Tissus, acc. no. MT 28928; see Bénazeth - Dal Prà 1991, and also below n. 17.

6 Ross 1940; Brooklyn 1941, no. 107.

Baltimore 1947, no. 159.

8 Der Narsessian 1941, 167.

9 Baltimore, The Walters Art Gallery, acc. no. 71.297; Brooklyn 1941, no. 108; http://art.thewalters.org/detail/6580/virgin-and-child-12/.

10 New York, The Pierpont Morgan Library, Mss. Morgan 612, Morgan 574, Morgan 597; Brooklyn 1941, nos. 12-14. 
Later on Ghirshman mentioned the ivory plaque in question as an example of the phenomenon of imitating Sasanian models in non-Iranian areas. He observed that the «ivorier copte» did not understand the details of the sovereign's clothing and crown, and he thus produced a «faible reflet du modèle original». ${ }^{11}$ The model Ghirshman was referring to is the enthroned sovereign on the "Khusraw Cup", whom he identified as Khusraw I. ${ }^{12}$

More recently Harper, dating the plaque to the $7^{\text {th }}$ century, has described it as "simple and crude in design» and - more cautiously - as portraying a "frontal image of an enthroned king wearing a crown decorated with vague, wing-like forms and superficially resembling that of a Sasanian king". ${ }^{13}$ She also observed that the king is not sitting on a couch throne (the couch throne is a typical feature of "post-Sasanian” enthronement scenes). ${ }^{14}$

Ross' conclusions are re-proposed in the online catalogue of the Walters Gallery. ${ }^{15}$

\section{OR AN UMAYYAD ARTEFACT?}

It is my contention that the Walters ivory plaque, whether it was made in Egypt or not, is not a Coptic artefact, nor a portrait of a Sasanian king, nor a misunderstood rendering of a Sasanian or post-Sasanian model. ${ }^{16}$ In the following I will rather infer that it is an Umayyad artefact. Indeed, though the iconographical model that inspired the artist of the Walters plaque can be traced back to the Sasanian and post-Sasanian tradition of representations of enthroned sovereigns, the specific features of the sovereign he carved refer to a specific Umayyad tradition of representing the enthroned Caliph.

\subsection{The Sasanian and Post-Sasanian Model}

The iconography characterizing the sovereign represented in the Walters plaque - a crowned sovereign sitting on a backless and armless throne and holding his sword vertically between his legs - appears in the portrayals of Bahrām II (276-293) and Shāpūr II (r. 309-379) carved into the rock at Naqsh-i Bahrām and Bishāpūr, ${ }^{17}$ respectively, and of the royal characters portrayed in a Kushano-Sasanian plate from Rawalpindi (London, British Museum, acc. no. 124093), ${ }^{18}$ a plate of uncertain provenance kept at the Walters Art Gallery (Baltimore, Walters Art Gallery, acc. no. 57.625), ${ }^{19}$ a plate from Strelka, in the Perm' kraj, Russia (Saint Petersburg, State Hermitage Museum, acc. no. S250), ${ }^{20}$ the central medallion of the "Khusraw Cup” (Paris, Bibliothèque nationale de France, acc. no.

1 Ghirshman 1962, 304.

2 Ghirshman 1962, 304, figs. 401 and 402.

13 Harper - Meyer 1981, $111 \mathrm{ff}$.

4 Harper - Meyer 1981, 99-123; see also von Gall 1971.

15 http://art.thewalters.org/detail/8959/seated-king/.

16 A representative example of a Coptic rendering of a Sasanian king is found in two fragmentary leggings found at Antinoe and datable to the second quarter of the $6^{\text {th }}$ and the first quarter of the $7^{\text {th }}$ century. They are kept at the Louvre, acc. no. E. 293232) and the Musée des Tissus in Lyon (acc. no. MT 28928). See Bénazeth - Dal Prà 1991.

17 Harper - Meyer 1981, 102-103, and figs. 25-27. «Relief IV» in the caption of fig. 27 should be emended to «Relief VI».

18 Harper - Meyer 1981, 108-110, fig. 35.

19 Harper - Meyer 1981, 115, 119-120, pl. 36.

20 Harper - Meyer 1981, 110-115, pl. 19. 
379), ${ }^{21}$ and in a plate from Klimova, in the Perm’ kraj, Russia (Saint Petersburg, State Hermitage Museum, acc. no. S43). ${ }^{22}$ However, the very posture held by the sovereign in the Walters plaque - except for the position of the feet in relation to the sword - and the stool-throne with decorated legs, only correspond precisely with the portrait of Bahrām II (fig. 6). ${ }^{23}$ Moreover, it should be noted that the crown worn by Bahrām II, unlike those of his predecessors and successors, featured eagle wings resting directly on a diadem and surmounted by a globe. ${ }^{24}$

The stylization of the crown, the facial characteristics, and the clothing of the sovereign represented in the Walters plaque are paralleled in two plates allegedly from Marw, datable from the $8^{\text {th }}$ to the $9^{\text {th }}$ century and kept at the Hermitage State Museum (figs. 8-9). ${ }^{25}$ They feature a royal hunting and a royal banqueting scene, respectively. As for the crown: in the former the crown is rendered as two wing-like elements parting in the middle and revealing a curved headgear, and in the latter as a diadem surmounted by two wing-like elements parted by a pentagonal element, possibly a jewel, surmounted by a crescent. In neither case does the crown feature flying ribbons or fillets. As for the facial characteristics: both figures have very elongated faces, small but plump lips, moustaches and rounded beards, and locks of hair falling to their ears; in the first plate the figure has oval lidless eyes and pierced pupils, and though the head is in a three-quarter view the nose is viewed frontally and the dorsal bridge is attached to the eyebrows; in the second plate the figure features more realistic traits which are seen in the nose, and in the eyes with thick eyebrows and lids, but no pupils. Both sovereigns have a halo around their head. As for the clothing, both figures wear a neckless short-sleeved caftan over a long-sleeved tunic tied at the waist with a belt and ruffled above the knees, which are covered by loose trousers narrowing at the ankles.

From this evidence we can conclude that the iconography of the sovereign in the Walters plaque is based on the portrayal of Bahrām II, but re-adapted as it appears in the Islamic plates from Marw.

\subsection{The Umayyad Tradition}

Almost all the features of the sovereign portrayed in the Walters plaque, with small variations due to the different media, state of preservation and skill of the artist, are found in analogous representations of royal figures produced in Islamic lands during the Umayyad period. The most famous example is a carved stucco found on the exterior of the palace at Qașr al-Hayr al-Gharbī (727/728) and possibly located in the lunette above the main entrance (fig. 2). ${ }^{26}$ Though broken into two fragments, the figure - the head of which is carved in high-relief while the rest of the body is in bas-relief - reveals traces of a crown, of

21 See n. 4.

22 Harper - Meyer 1981, 118-119, and pl. 35.

23 After the recent survey and tracing by Klimburg-Salter, the painting of a figure seated on a throne found at Dukhtar-i Nūshirwān appears to be a deity holding his sword diagonally with his left hand and not a sovereign holding his sword vertically with both hands; see Klimburg-Salter 1993, pl. 87.

24 See Shahbazi 1988. The crown of Hormazd II is similar, but a row of pearl or pearl-like elements is interposed between the diadem and the wings. In addition, no portrayals of Hormazd II enthroned are known so far. For the crowns of Sasanian kings see Azarpay 1972, and Erdmann 1951.

25 Marshak 1986, nos. 29-32.

26 Schlumberger 1986, 15, 22. 
which the right wing-like element and the central pentagonal jewel still remain; traces of hair falling to the ear, part of the beard, and an eye with a big painted pupil but no lid surmounted by an eyebrow joining the nose at the dorsal bridge; the upper part of a neckless caftan or tunic with heavy drapery, ornamented in the middle by a row of pearls or a pearl-like ornament running downwards and maybe originally reaching the waist; part of the shoulders and the upper arms oriented slightly outward, thus suggesting that the arms were bent at the elbows; the lower part of the body with the legs bent outward at the knees and covered by the ruffled lower part of the tunic or caftan falling into the lap at knee height, with a pearl-like ornamented rim, and loose trousers narrowing at the heels; a fragment of the left foot in a three-quarter view with the heel lifted. The ruffling of the tunic/caftan and trousers is rendered by heavy drapery. Though the crown, posture, and clothing suggest that the figure originally held a sword between its legs, other possibilities remain. In another example of Umayyad royal imagery comparable to the Walters plaque, found in a fragment of textile datable to the $7^{\text {th }}-8^{\text {th }}$ century and kept at the David Collection in Copenhagen (acc. no. 23/2011; fig. 3), ${ }^{27}$ the sovereign does not hold a sword but rather a flower in each hand. However, he sits frontally on an armless and backless throne supported by legs resting on the head of two ibexes facing each other in profile; though the angle formed by his thighs and calves is less emphasised, nonetheless the legs are bent at the knees and the arms are bent at the elbows; his face is round but has a pointed chin, the mouth is not visible though room for it is left between the moustache and beard; the nose is seen frontally and its point is quite realistic; the dorsal bridge joins the eyebrows which surmount wide oval eyes with a big pupil but no lids; the hair falls to the ears, which wear earrings; the crown on the head consists of a diadem with two wings rising above it and above them, almost floating in the air, is a jewel-like element reminiscent of the crescent that topped the Sasanian crown. The head is haloed. As for the clothing, the sovereign wears a neckless long-sleeved tunic or caftan ornamented by rows of pearls or pearl-like elements and roundels. The folding of the lower rim of the garment suggests that he is wearing trousers. His feet are turned outward at $180^{\circ}$, the heels are lifted and the toes point downward but they do not rest on the rectangular element placed beneath them resembling a footstool. The figure, which is repeated four times on the fragmentary textile, is placed between imaginary trees: from their trunks grapes, vine-leaves and flower-like fans studded with pearls sprout out symmetrically on either side and the trunk is topped by a composition of plume-like leaves supporting a crown-like flower studded with jewels, the petals of which are arranged like the crown worn by the sovereign. The composition of these plants - tree of life/axis mundi ${ }^{28}$ - and their single elements - real and imaginary vegetal motifs, plumes and jewels - parallel those found in the mosaics of the Dome of the Rock (691/692). ${ }^{29}$ Another example of this royal iconography belonging to Umayyad contexts consists of two images carved on ivory plaques which were found at al-Humayma in Jordan, in a residence presumably belonging to the 'Abbāsid family before its accession to the throne, and thus to the first half of the $8^{\text {th }}$ century. ${ }^{30}$ These two plaques (fig. 4),

27 https://www.davidmus.dk/en/collections/islamic/materials/textiles/art/23-2011.

28 Fontana 2007.

29 van Berchem in Creswell 1979.

30 Foote 1999; Oleson - Amr - Foote 1999; Evans - Ratliff 2012, 221-222 and no. 153 A-C. 
measuring approximately $10 \times 30 \mathrm{~cm}$, along with another four of the same size, were furniture veneer panels, like the ones found at Ayla, ${ }^{31}$ as revealed by the holes left by the nails used to fix them to the surface they covered, and fragments of wood and fasteners discovered nearby. ${ }^{32}$ Although they were found burned and crushed, the essential features of the male human figures carved on each of them are quite recognisable. Four of them have been identified as soldiers - they are seen in profile with their heads haloed and their clothing consists of a helmet, tunic, possibly chain mail and loose trousers, and they hold a spear diagonally. Two have been described as identical to the previous ones, «seated frontally, on a throne (?), wearing a diadem (?), and holding a staff (?) vertically in front of themselves». ${ }^{33}$ Their clothing has been identified as Persianate, whereas the soldiers' headgear appears to be Caucasian or Central Asian, thus suggesting that the panels were produced in Sogdia, Persia, or the Indian subcontinent. This has been interpreted as testifying to a connection between the 'Abbāsid headquarter at al-Ḥumayma and Khurāsān on the eve of the 'Abbasid revolution. ${ }^{34}$ The panels rather seem to be part of two identical scenes arranged in two triptychs: an enthroned sovereign flanked by two soldiers or guards. The iconography of the latter is quite clear, as it is that of the former. Indeed, the sovereign sits on a backless and armless seat, his arms are bent outward at the elbows and his hands hold a sword - the right hand is on its pommel, the left grips the hilt where the guard should be, as in the portrayals of Bahrām II, standing at Naqsh-i Rustam and sitting at Naqsh-i Bahrām - positioned vertically between his legs. The pearl-like ornamentation of the sword suggests that it is inserted into a scabbard - as in the portrayal of the standing Bahrām at Naqsh-i Rustam (fig. 7) and the standing Pīrūz or Khusraw II or Ardashīr III at Țāq-i Bustān. ${ }^{35}$ The angle between the thigh and the calf is not emphasised - as in the textile from the David Collection - but nonetheless the legs are bent, as revealed by the remains of the backless and armless throne still visible in one of the panels (fig. 4, on the right). The feet are joined to the point of the scabbard and turned outward at $180^{\circ}$. The clothing consists of a long-sleeved caftan/tunic reaching the knees, worn over loose trousers narrowing at the ankles. A row of pearls or pearl-like elements runs along the upper and lower rims of the caftan/tunic, possibly over the belt, and along the lateral profile of the trousers - as in the portrayal of the sovereign at Qașr al-Hayr al-Gharbī. The head is haloed, the face elongated, with no moustache or beard, and features Central Asian traits. The hair is very thick and compressed in order to fit into the upper frame of the panel where there is a crescent attached to the diadem, in the middle, covered by pearls or pearl-like elements. The hair is parted symmetrically to the right and left of the face: the upper locks resemble wings, the lower ones spring from beneath the ears and coil upwards into a curl. The head is also haloed. One of the soldiers/guards is placed beneath a horseshoe arch resting on decorated capitals. ${ }^{36}$

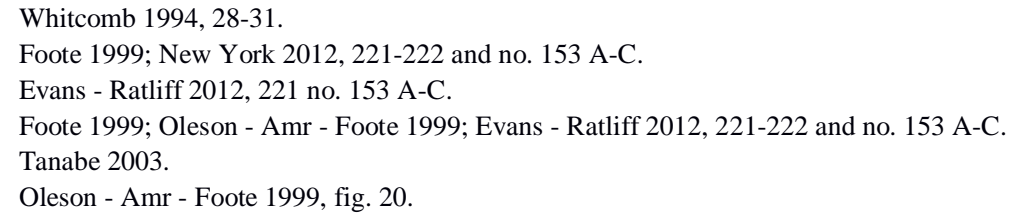


Another example of this royal iconography can be seen in a stucco panel found at Qașr al-Hayr al-Sharqī (fig. 5), in the recently excavated building E. ${ }^{37}$ The panel is fragmentary but its original measurements can be reconstructed as $50 \times 70 \mathrm{~cm}$ through comparison with the two analogous figurative panels discovered together with it along the north-western corner of the eastern court of the building. ${ }^{38}$ It features a male human figure resting its feet on the lower frame and surrounded by a vegetal composition, possibly an arch, as in the panel featuring a male figure mounted on a horse and holding a falcon in his right hand. ${ }^{39}$ The fragments allow us to re-construct the representation of a bearded man seen frontally, with his arms bent at the elbows, his hands holding a sword in a scabbard - the right seems to grasp the pommel of the hilt, the left possibly its grip - set vertically and falling between his feet, which are turned outward at $180^{\circ}$. The sitting sovereign from Qașr al-Hayr alGharbī, the standing sovereign from Khirbat al-Mafjar and the "Standing Caliph" on the coins issued by 'Abd al-Malik (685-705) between 691/692 and 696 have been deemed as more suitable comparisons, along with representations of Sasanian kings on rock reliefs and metals, and a standing figure represented in a stone relief found in a church in Ctesiphon dating to the Sasanian period. ${ }^{40}$ However, the standing sovereign at Khirbat al-Mafjar, of which only the lower parts of the head and body remain, holds the sword diagonally on his left side, grasping its hilt at the grip with his left hand; ${ }^{41}$ the "Standing Caliph" also holds the hilt of the sword in a scabbard or the khutb diagonally, but with his right hand; ${ }^{42}$ the Sasanian kings portrayed in monumental art as standing frontally and holding their sword vertically with both hands have their head seen in profile or in a three-quarter view; ${ }^{43}$ the only example of a Sasanian king standing frontally and holding a sword vertically with both hands is found in a portrayal of Khusraw II on a golden coin issued by him, ${ }^{44}$ and in his representation in the takht-i tâaqdis on a post-Sasanian plate from Qazwīn (Tehran, Iran Bastan Museum, acc. no. 904); ${ }^{45}$ of the standing figure from Ctesiphon only the lower part of the body survives, the hands are also lost, and the position between the parted feet is occupied by a spear or a pike, while part of a sword in a scabbard appears behind it, set diagonally. Therefore, the closest terms for comparison with the panel from Qașr al-Hayr al-Sharqi seem to be the frontal representations of sitting sovereigns belonging to the Umayyad tradition. On the other hand, there is still the possibility that the bearded man was sitting on a throne and not standing. Indeed, his tunic begins to flare well beneath the waist where his knees should be: this flaring may symbolize the bending of the legs and, consequently, a sitting position. This very ambiguity between the iconography of the enthroned sovereign and the standing sovereign is found in the aforementioned post-

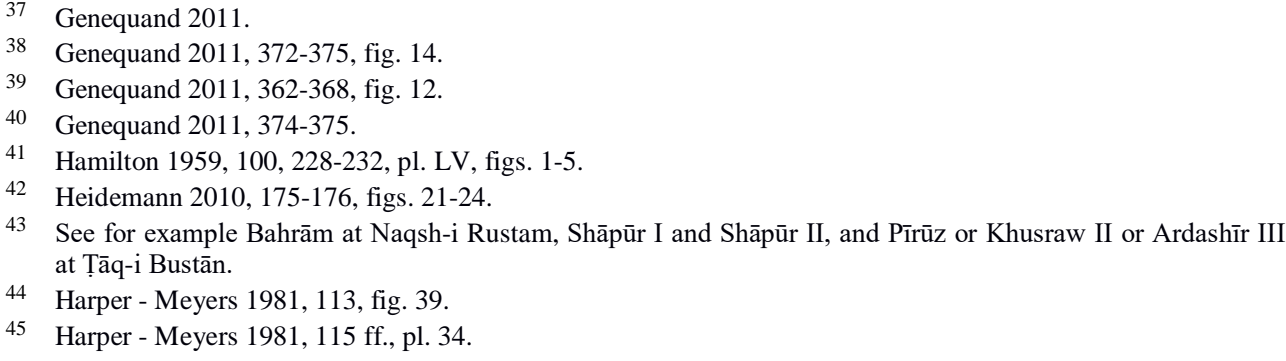


Sasanian plate from Qazwīn. There a couch-throne is placed behind the figure whereas in

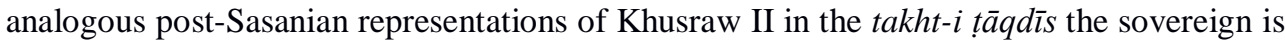
sitting on such a throne. ${ }^{46}$

In any case, the similarities of the Walters plaque with the panel from Qașr al-Hayr alSharqi also involve the presence of vegetal elements in relation to the architectonic space framing the figure, which in both cases is an arch. We have also mentioned that one of the soldiers/guards in the al-Humayma plaques is placed underneath an arch supported by capitals. Other elements characterizing the Umayyad artistic language can be detected in the Walters plaque: the vine-leaf appearing in the reversed semi-arch in the Walters plaque is identical in shape and in the rendering of the main veining to the leaves carved on an Islamic ivory pyxis kept at the Victoria and Albert Museum (acc. no. 136-1866), which is datable to the $7^{\text {th }}-8^{\text {th }}$ centuries and was possibly manufactured in Egypt or Syria; ${ }^{47}$ the shape of the eyes of the sovereign, lidless with protruding eyeballs and pierced pupils, is typical of several human heads found at Khirbat al-Mafjar. ${ }^{48}$

\section{CONCLUSIONS}

The iconographical and stylistic analysis of the Walters plaque reveals that it is an Umayyad artefact and that it should be considered along with analogous representations of enthroned sovereigns produced in the $d \bar{a} r$ al-Islām in the late $7^{\text {th }}$ and early $8^{\text {th }}$ centuries. While these representations are clearly reminiscent of Sasanian royal imagery, their comparison implies that the artists did not freely rely on the latter but rather referred to a specific Islamic model shaped after the portrait of Bahrām II at Naqsh-i Bahrām. Indeed, the occurrence of such precise features, such as the stool-throne, the posture of the figure, its clothing and insignia leads to the identification of a common archetype. In addition, the shape of the crown, which appears to be a stylization of Bahrām II's crown, clearly highlights that the royal figure represented in these artefacts is not a Sasanian king: the crown worn by Khusraw II in the famous painting of the six kings in the reception hall of Qusayr 'Amra is shaped almost exactly like the crown worn by Khusraw II on the coins he issued, thus identifying the character as the Sasanian king. ${ }^{49}$ Therefore, the Umayyad iconography of the enthroned sovereign with a winged crown and sword depersonalizes the Sasanian royal imagery and reduces it to its essential symbolical meaning, namely royal power divinely bestowed. Thus, the portrait of Caliphal authority emerges. This reasoning endorses the identification of the sitting sovereign at Qașr al-Hayr al-Gharbī - and the analogous representations - as the Caliph, ${ }^{50}$ however not as a specific Caliph but on the contrary as the symbol of Umayyad Caliphal authority: a dynasty chosen by God to rule all

46 Bonhams, London. Auction 19961, Lot 177, 25 Apr 2012; Boston, Museum of Fine Arts, acc. no. 57.587; Saint Petersburg, Hermitage State Museum, acc. no. S43. In the second the sovereign holds a spear or a pike in his right hand and a sword in his left; in the third the sovereign has his legs crossed.

47 Evans - Ratliff 2012, 177-17 no. 120B.

48 See for instance Hamilton 1959, pls. XXII.1, 4; XXXV.1; LIII.2; LVI.2 and 3; LIX.3.

49 On this topic see the contribution by C.-P. Haase, entitled "Representations of Rulers with their Regalia and Epigraphical Denominations", presented at the international conference The Colours of the Prince: Conservation and Knowledge in Qusayr 'Amra, held in Rome from 22 to 23 October 2014, the proceedings of which, edited by G. De Palma - F. Anzelmo, are currently in press.

50 Schlumberger 1986, 15, 22; Creswell 1979, 510-511. 
over the world as His deputy on earth. ${ }^{51}$ This ideological framework also constitutes a starting point for investigating the meaning and purpose of the representations of royal figures in Byzantine/Western garb found at Qașr al-Hayr al-Gharb̄̄ and Qușayr 'Amra, which are respectively paired by the representation of the Caliph and a princely figure in Sasanian/Eastern garb, ${ }^{52}$ which will be dealt with in a future contribution.

\section{REFERENCES}

AZARPAY, G.

1972 Crowns and Some Royal Insignia in Early Iran: Iranica Antiqua 9 (1972), pp. 108-115.

BALTIMORE

1947 Early Christian and Byzantine Art: An Exhibition Held at the Baltimore Museum of Art, April 25-June 22 Organized by The Walters Art Gallery, in Collaboration with the Department of Art and Archaeology of Princeton University and Dumbarton Oaks Research Library and Collection of Harvard University, Baltimore 1947.

BÉNAZETH, D. - DAL PRÀ, P.

1991 Une paire de jambières historiées d'époque copte, retrouvée en Égypte: La revue du Louvre et des Musées de France 3 (1991), pp. 16-29.

BROOKLYN

1941 Pagan and Christian Egypt: Egyptian Art from the First to the Tenth Century A.D. Exhibited at the Brooklyn Museum by the Department of Ancient Art, January 23-March 9 1941, Brooklyn 1941.

CRESWELL, K.A.C.

1979 Early Muslim Architecture, 1. Umayyads A.D. 622-750, New York 1979 (revisited edition of Oxford 1969).

CRONE, P. - Hinds, M.

1986 God's Caliph: Religious authority in the first centuries of Islam, Cambridge - London New York - New Rochelle - Melbourne - Sydney 1986.

DER NARSESSIAN, S.

1941 Review of Pagan and Christian Egypt: The Art Bulletin 23 (1941), pp. 165-167.

ERDMANN, K.

1951 Die Entwicklung der sasanidischen Krone: Ars Islamica 15-16 (1951), pp. 87-123.

EvANS, H.C. - RATLIFF B. (eds.)

2012 Byzantium and Islam: Age of Transition, 7th-9th Century, New York 2012.

FONTANA, M.V.

2007 La croce nell'iconografia islamica: B. UliAnICH (ed.), La Croce: Iconografia e interpretazione (secoli I-inizio XVI), Atti del convegno internazionale di studi (Napoli, 6-

FOOTE, R.M. 11 dicembre 1999), Napoli 2007, II, pp. 231-267.

1999 Frescos and Carved Ivory from the Abbasid Family Homestead at Humaima: Journal of Roman Archaeology 12 (1999), pp. 423-428.

51 Crone - Hinds 1986

52 The case of Qusayr 'Amra has been recently investigated by M.V. Fontana in a contribution entitled "Qusayr 'Amra, ca. 740 C.E.: amīr al-Walīd Reclining and Dressed According to Iranian Fashion”, which will appear in the Festschrift Prof. Adriano Rossi, edited by S. Badalkhan - G.P. Basello - M. De Chiara, and currently in press. 
GENEQUAND, D.

2011 Les décors en stuc du bâtiment E à Qașr al-Hayr al-Sharqī: Syria 88 (2011), pp. 351-378.

GHIRSHMAN, R.

1962 Iran: Parthes et Sassanides, Paris 1962.

HAMILTON, R.W.

$1959 \quad$ Khirbat al Mafjar: An Arabian Mansion in the Jordan Valley, Oxford 1959.

HARPER, P.O. - MEYERS, P.

1981 Silver Vessels of the Sasanian Period. Volume One: Royal Imagery, New York 1981.

HEIDEMANN, S.

2010 The Evolving Representation of the Early Islamic Empire and Its Religion on Coin Imagery: A. NeUWIRTH - N. SinAI - M. MARX (eds.), The Qur'ān in Context: Historical and Literary Investigations into the Qur'ānic Milieu, Leyden - Boston 2010, pp. 149-195.

KLIMBURG-SALTER, D.

1993 Dokhtar-i Noshirwan (Nigar) Reconsidered: Muqarnas 10 (1993), pp. 355-368.

MARSHAK, B.

1986 Silberschätze des Orients: Metallkunst des 3-13. Jahrhunderts und ihre Kontinuität, Leipzig 1986.

Oleson, J. P. - AMR, K. - FOOTE, R.

1999 Preliminary Report of the Humayma Excavation Project 1995, 1996, 1998: Annual of the Department of Antiquities of Jordan 43 (1999), pp. 411-450.

Ross, M.C.

1940 A Coptic Bone Carving: Bulletin de la société d'archéologie copte 6 (1940), pp. 123-126. SCHLUMBERGER, D.

1986 Qasr el-Heir el-Gharbi, Paris 1986

SHAHBAZI, S.

1988 Bahrām II: Encyclopaedia Iranica, III, Costa Mesa (California) 1988, pp. 514-522.

TANABE, K.

2003 The Identification of the King of Kings in the Upper Register of the Larger Grotte, Taq-i Bustan: Ardashir III Restated: M. Compareti - P. RAFFETTA - G. SCARCIA (eds.), Érān ud Anērān: Studies presented to Boris Ilich Marshak on the Occasion of His $70^{\text {th }}$ Birthday, VON GALL, $\mathrm{H}$. online: http://www.transoxiana.org/Eran/Articles/tanabe.html.

1971 Entwicklung und Gestalt des Thrones im vorislamischen Iran: Archaeologische Mittelungen aus Iran n. F. 4 (1971), pp. 207-236.

Wнітсомв, D.

1994 Ayla: Art and Industry in the Islamic Port of Aqaba, Chicago Illinois 1994. 


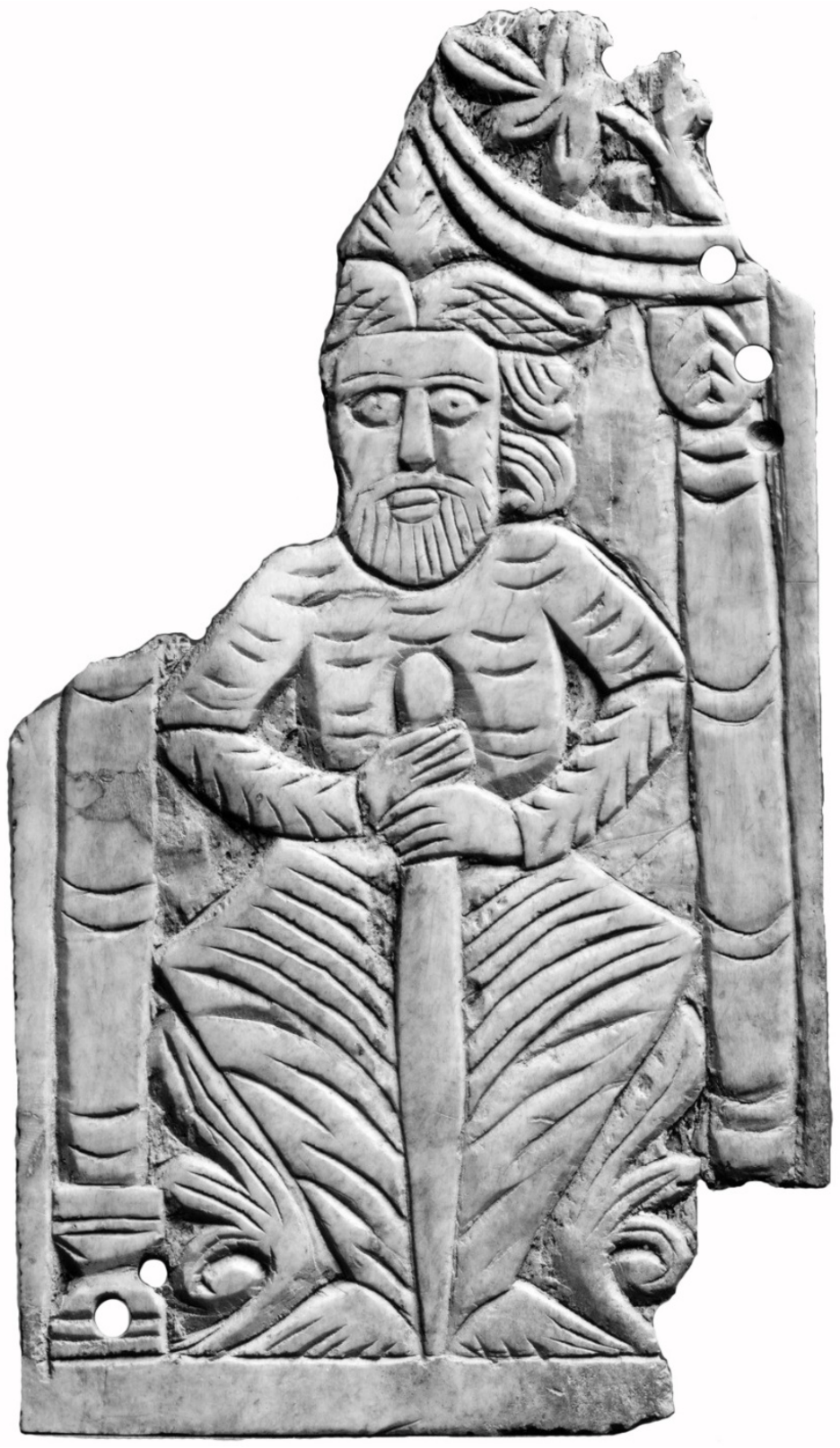

Fig. 1 - Carved ivory plaque depicting a seated sovereign, possibly from Egypt, $7^{\text {th }}-8^{\text {th }}$ century, The Walters Art Gallery, acc. no. 71.62 (http://art.thewalters.org/detail/8959/seatedking). 

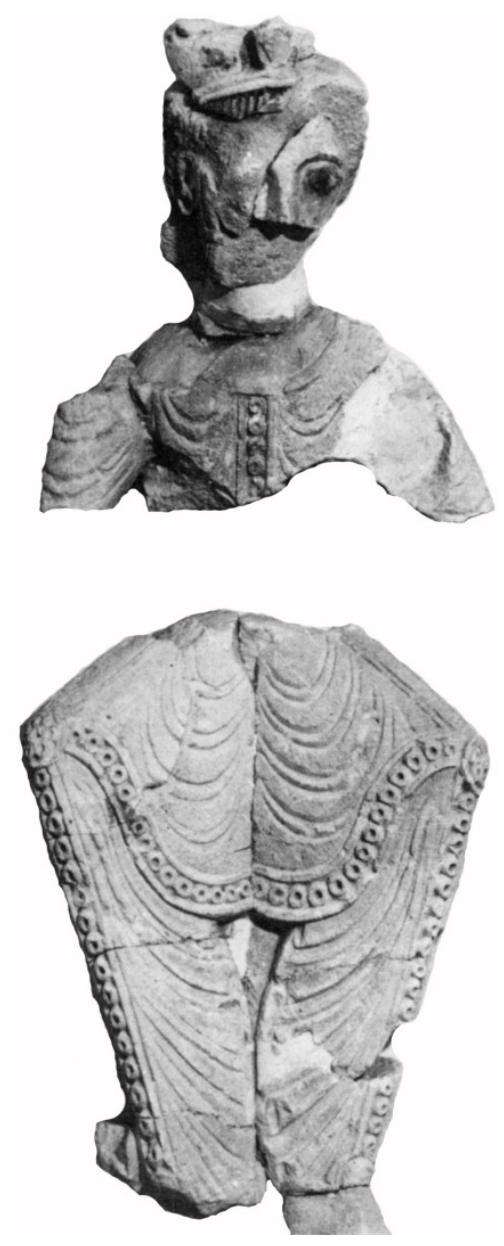

Fig. 2 - Carved stucco relief portraying a sovereign, found at Qașr al-Hayr al-Gharbī, 727/ 728, National Museum of Damascus (after Schlumberger 1986, pl. 64).

Fig. 3 - Samitum-woven silk textile depicting a seated sovereign, possibly made in Iran or Central Asia, $7^{\text {th }}-8^{\text {th }}$ century, The David Collection, Copenhagen, acc. no. 23/2011 (www.davidmus.dk/en/collections/islam ic/materials/textiles/art/23-2011, detail).

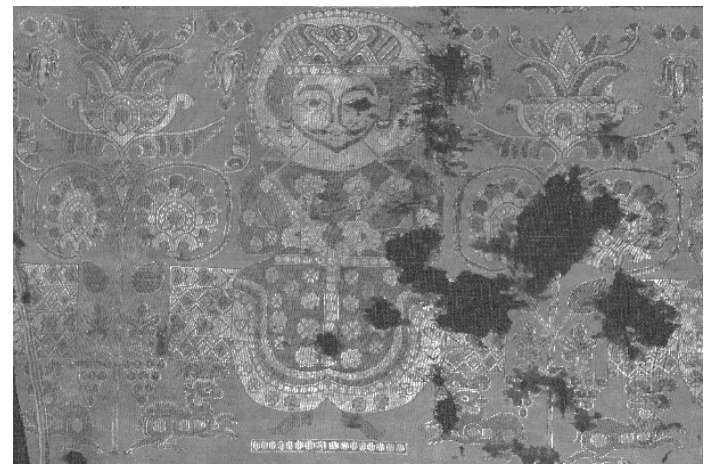


Fig. 4 - Carved ivory plaques depicting a seated sovereign, found at al-Humayma, possibly made east of the Euphrates river, first half of the $8^{\text {th }}$ century, under the Department of Antiquities, 'Amman (after Evans - Ratliff 2012, ills. A and C on p. 222).
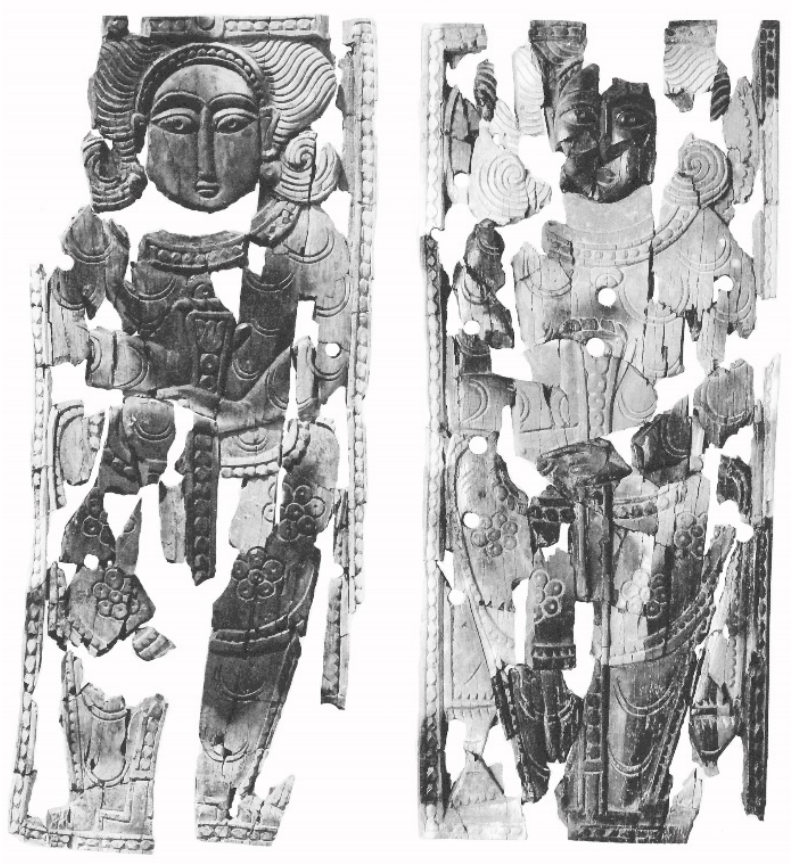

Fig. 5 - Carved stucco panel possibly depicting a seated sovereign, found at Qașr al-Hayr al-Gharbī, 727 ca., current location unknown (after

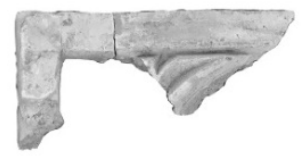
Genequand 2011, fig. 14).

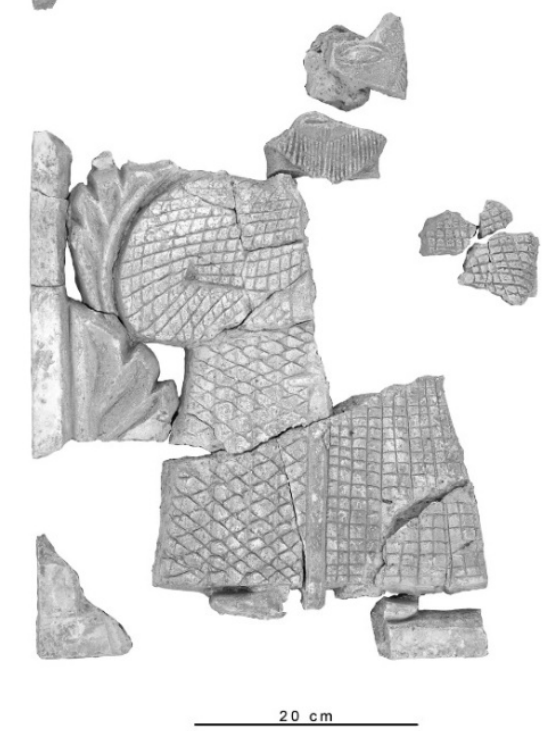




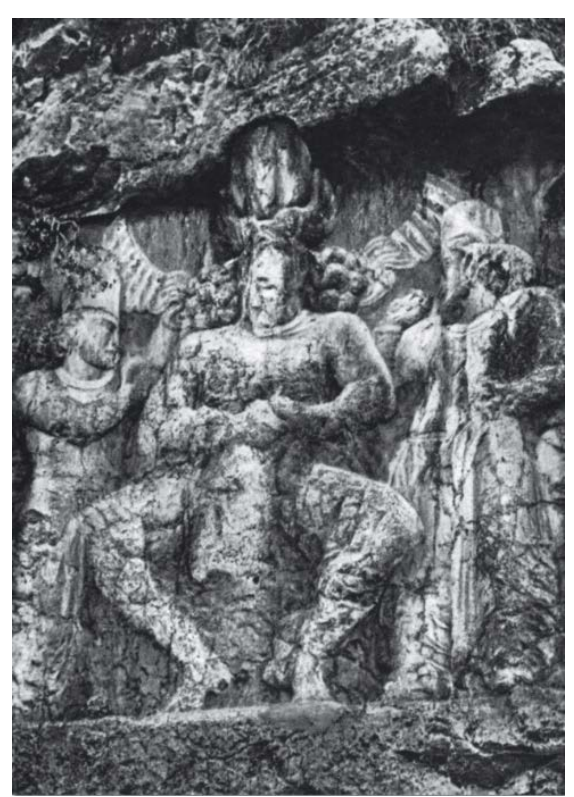

Fig. 6 - Naqsh-i Bahrām, rock relief portraying Bahrām II (276-293) enthroned (after Ghirshman 1962, fig. 214, detail).

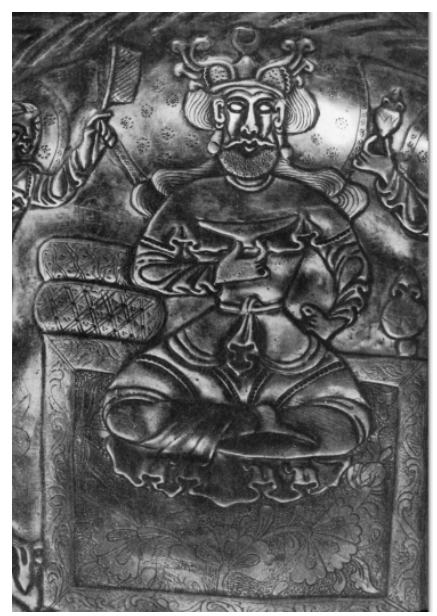

Fig. 8 - Silver plate depicting a hunting sovereign, allegedly from Marw, $8^{\text {th }}-9^{\text {th }}$ century, Hermitage State Museum, Saint Petersburg (after Marshak 1986, fig. 29, detail).

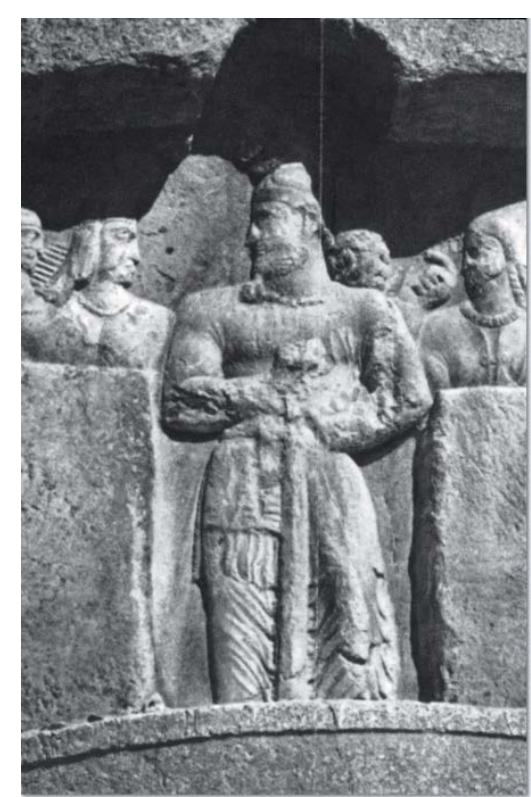

Fig. 7 - Naqsh-i Rustam, rock relief portraying Bahrām II (276-293) standing (after Ghirshman 1962, fig. 213, detail).

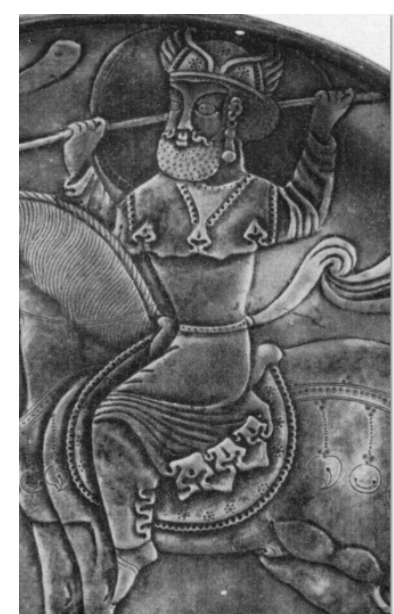

Fig. 9 - Silver plate depicting a banqueting sovereign, allegedly from Marw, $8^{\text {th }}-9^{\text {th }}$ century, Hermitage State Museum, Saint Petersburg (after Marshak 1986, fig. 31, detail). 